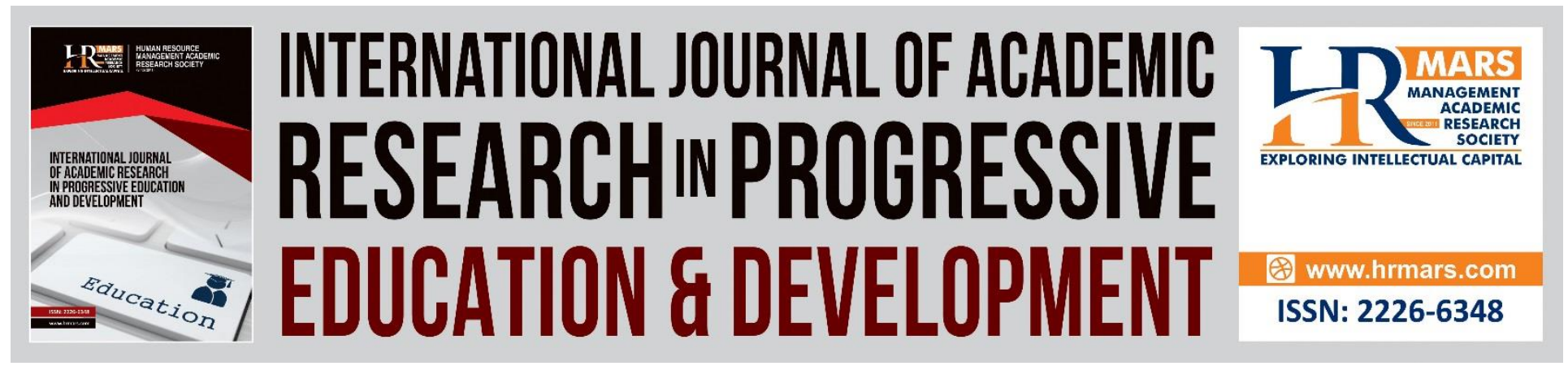

\title{
Student Teachers Challenges in the Preparation and Implementation of Microteaching: The case of the National University of Lesotho
}

\section{Teboli David Makafane}

To Link this Article: http://dx.doi.org/10.6007/IJARPED/v9-i2/7283

DOI:10.6007/IJARPED/v9-i2/7283

Received: 18 January 2020, Revised: 20 February 2020, Accepted: 12 March 2020

Published Online: 30 March 2020

In-Text Citation: (Makafane, 2020)

To Cite this Article: Makafane, D. T. (2020). Implementation of Microteaching: The case of the National University of Lesotho. International Journal of Academic Research in Progressive Education and Development, 9(2), 144-157.

Copyright: (C) 2020 The Author(s)

Published by Human Resource Management Academic Research Society (www.hrmars.com)

This article is published under the Creative Commons Attribution (CC BY 4.0) license. Anyone may reproduce, distribute, translate and create derivative works of this article (for both commercial and non-commercial purposes), subject to full attribution to the original publication and authors. The full terms of this license may be seen at: http://creativecommons.org/licences/by/4.0/legalcode

\section{Vol. 9(2) 2020, Pg. $144-157$}




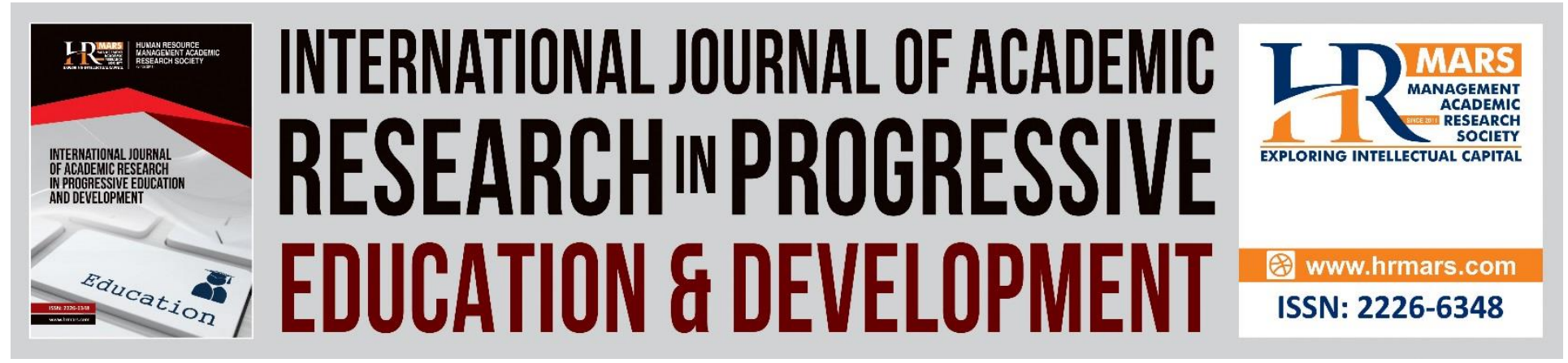

\title{
Student Teachers Challenges in the Preparation and Implementation of Microteaching: The case of the National University of Lesotho
}

\author{
Teboli David Makafane \\ National University of Lesotho, Faculty of Education, Department of Educational Foundations \\ P O Roma 180, Lesotho, Southern Africa \\ Email: dtmakafane@gmail.com
}

\begin{abstract}
The study adopted qualitative research approach to investigate the challenges experienced by student teachers during microteaching in the Faculty of Education at the National University of Lesotho. Data for this study was collected during the supervision of students while carrying out pre-microteaching activities such as interpreting the syllabus, planning and rehearsing for their sessions; during their oral presentations and from their written materials. The data was collected using observations and semi-structured interviews. The information collected was recorded in a form of field notes, which were later transcribed and analysed using a thematic approach. Findings revealed that the challenges faced by the student teachers in the microteaching activities are the use of English as a medium of communication; interpretation of the syllabus; selection of teaching methods; over and under planning and organisational strategies. It is recommended that student teachers be discouraged from using non-conventional language, use both curriculum and syllabus when planning a lesson, adopt different teaching methods, compile their microteaching portfolios way ahead of time.

Keywords: Challenges in Microteaching, Student Teachers, Curriculum Interpretation, Lesson Planning and Implementation.

\section{Introduction}

This study investigated the student teacher's challenges in the preparation and implementation of microteaching at the National University of Lesotho. It is significant to look at teachers training issues as some of them inform their profession. This study has background information, teaching practice as a teacher training lengthy practice. The research problem, method of data collection population and sampling as well as results are captured in this paper.
\end{abstract}




\section{Background Information}

The existing curriculum of the Faculty of Education at National University of Lesotho (NUL) provides various types of teacher education programmes at the undergraduate as well as graduate levels (NUL, 2019). Higher Diploma in Education is offered as a two-year part-time programme to primary school teachers who want to upgrade from college level teaching diploma qualification. After acquiring this qualification, student teachers can choose to continue to study for two more years in order to attain an undergraduate degree teaching qualification. Secondary school teacher education programme offers two types of qualifications: undergraduate diploma in Agriculture, and Bachelor's degree in various learning areas of social sciences and languages, special education, and pure science education. Diploma in Agriculture program is a one-year programme offered mostly to students who have a diploma qualification in Agriculture from the Lesotho Agriculture College (NUL, 2019).

The duration of secondary teacher education degree programme is four years. Student teachers enrolled in the undergraduate degree in teacher education programme are of two main categories: student teachers who are upgrading from college level teaching diploma for secondary education level or to undergraduate teaching degree level. This category of student teachers is normally exempted from the first year of the programme and are taken directly into the second year class of the programme. Another category of student teachers are those admitted in the programme directly after successful completion of high school education. These type of students go through the four years of the programme. The focus of this study is on the secondary teacher education programme which awards Bachelor of Education and Bachelor of Science Education degree (B.Ed. and B.Sc.Eds.) qualification on completion.

Teacher education program for secondary teachers at NUL comprises three types of courses namely: content, curriculum, and education foundational courses. Content courses are offered in other faculties such as the Faculty of Humanities, the Faculty of Social Sciences and the Faculty of Science and Technology. Curriculum courses, which basically train teachers how to teach content in their specialisations, are offered in the Department of Languages and Social Science Education (LASED) and the Department of Science Education. As part of the requirements of the programme, student teachers are also required to take courses offered in the Department of Educational Foundations (EDF). EDF courses are offered as core and electives. Introduction to Philosophy of Education is offered as a core course in the first year of study. All student teachers in the second year of study take Educational Psychology, and Teaching and Instructional Design as core courses. In the third and fourth years of study, EDF courses are offered as electives in the areas of assessment and evaluation, clinical supervision, and non-formal education to mention a few. Teacher education programme for secondary school teachers has eight semesters and courses are offered as a semester (three credit hours) or a year course (6 credit hours) courses. The last semester of the programme is normally reserved for the teaching practice programme. Student teachers get theory part at the national University and they are expected to go for teaching practice on their final year, however before they go for teaching practice they should go through microteaching which assist them with classroom issues, curriculum and syllabus interpretation 
DEVELOPMENT

Vol. 9, No. 2, 2020, E-ISSN: 2226-6348 @ 2020 HRMARS

\section{Teaching Practice}

At the National University of Lesotho every student in teacher education program is expected to attend teaching practice during his/her final year of study. The intended program assists students to put in practice the theories and teaching models which they were taught during their tenure in their respective streams. This concept is not isolated from other countries or other universities as Wagenaar (2005) stated that in South Africa all student teachers are expected to do practice teaching which helps them to conduct teaching trials in the context of a school situation in order to fine tune the skills required of a teacher.

Teaching practice is a programme that is intended to support student teachers for some months. It is an intensive process which is meant to impress upon the student teacher so that they can appreciate the progress of learning as well as reflect on what they have learned. Lewin (2004) observed that at one or more points during the training period, trainees spend anything from a few days to a several months working in schools as classroom teachers under supervision. This allows the supervisor to explore various theories or models which the student teacher wants to employ and then assist them.

Teaching practice is a compulsory and forced initiative in universities or colleges of education. It is said to be an important tool which is designed to equip student teachers with techniques to sharpen their teaching skills. Chepyator-Thomson and Hsu (2007) outlined that many researchers consider teaching practice to be the most significant section of undergraduate teacher preparation programs. It is part of an educational journey which may be regarded as internship when using the terminology of other disciplines. Other scholars refer to it as "practicals". Practical experience at schools is regarded by the University of Fort Hare's Education Department to be crucial for the successful completion of mentorship of students who are training to be future teachers (Irvin, Weslaway \& Schaefer, 2004).

USAID (2015) argues that it is also noteworthy to realize that although teaching practice appears to most people as the first stage of a teaching career, the informal phase in learning to teach begins much earlier. The person starts to learn how to teach the moment they enter the classroom as they view the person delivering the lesson and even imagine how they themselves, can deliver the lesson. The first stage in the continuum of learning to teach is known as the apprenticeship of observation, the period when the student teacher participates in and completes a formal teacher preparation program which enables him or her to acquire the knowledge, skill and attitudes. It is crucial for student teachers to be equipped for this task so that they could implement theories which they were taught. It is through preparation for the teaching practice that major activities like microteaching are put in place.

Microteaching is one of the compulsory courses offered in the second year, it is taken by all second-year students. In this programme, students participate in a number of activities such as identifying levels of objectives for planning of teaching, drawing a lesson plan and implementing a lesson plan. Microteaching has long been viewed as an important strategy in teacher education (Higgins \& Nicholl, 2003). It can be traced back to the early 60's. Often this strategy is designed with the purpose of giving student teachers an opportunity to practise teaching before participating in a field/practical based (school-based) teaching programme. Even today, microteaching is practised worldwide as an important element of teacher education (Remesh, 2013). 
Student teachers participating in microteaching programmes are exposed to opportunities to perk up their teaching skills by engaging in various simple teaching tasks. Bell (2007) also asserts that student teachers who are pursuing educational methods courses commonly practice microteaching. These students are exposed to preparing and teaching a lesson to their peers to gain experience. Student teachers plan and implement small teaching tasks which take only few minutes. It involves the clinical supervisor and the student teacher, who will have other students as observers too so that they can learn from the particular student on the platform. The planning and delivery of the lesson is not just promoted without employing teaching skills. Quinn (2000) adds that microteaching is a small group activity that can be a potent tool for the acquisition of skills. He further asserts that microteaching is a cycle of events, which consists of the performance of micro-skills which are aspects of a social or psychological skill such as questioning.

Bagatur (2015) asserts that microteaching is a structured programme which involves steps and phases. It is designed in phases so that it can help student teachers and clinical supervisors to follow prescribed patterns so that they do not skip important procedures. There are four basic phases in micro teaching; Student identify content and plan for it, then teach, get feedback from supervisor and peers. The first step the trainee studies a specific teaching skill and then conducts it in a small portion of the lesson. The second step is where the student teacher present the lesson. The third step is when the trainee receives feedback about the quality of their performance from the supervisor and the last one takes place when they receive a feedback from the classmates and clinical supervisor (Dweitkat, 2009). These phases could resume even some months prior to the micro teaching proper as it involves planning how microteaching will be conducted. This therefore, translates to the reason why teachers have to come up with end-oflevel objective of the lesson, interpret it by looking at the knowledge need in examining the objective verb; then out of the verb the student teacher should come up with indicators which will help in the formation of lesson objectives (Dweitkat, 2009).

This is still the same trend even at the National University of Lesotho as it prepares students teachers to be familiar with different models when designing a lesson, to be able to interpret a set syllabus as well as being aware of the curriculum set by the nation. This therefore seems to be a standard requirement with other universities which are involved in teacher training and across the globe. At Stanford University, a circle of microteaching involves the following steps being to 'plan, teach, observe, re-plan, re-teach and re-observe' (Brown, 1975). It is obvious that microteaching cannot be done once but rather it involves a repetitive action involving monitoring and redo of the same activities to rectify observed mistakes that crept into the process during its execution. Higgins and Nicholl (2003) assert that the University of Ulster amended this model into a three stage model comprising planning, teaching and observation.

Microteaching does not only benefit student teachers but it is also advantageous to the clinical supervisors as they keep themselves updated on the different models that keep are emerging, and that can be used to supervise the student teachers. It also promotes the skill of cooperation and teamwork for student teachers as they form groups when going into the microteaching laboratory. Okeke, Abongdia, Olusola, van Wyk and Wolhuter (2019) points out that other benefits of microteaching and view the strategy as useful for allowing the rehearsal of teaching techniques on a small scale without the fear of the consequences of failure. Therefore, 
microteaching works as a practice to all people who intend to be professional teachers. Microteaching or reflective practice is purported by many qualified teachers and educational scholars to have benefited pre-service teachers (trainee teachers) in the teacher learning profession to become competent teachers (Kuswando, 2014).

In microteaching, there are numerous facilities which are used by both the clinical supervisor and student teachers. The list starts from the blackboard, white board marker and other typical classroom tools that are found in a typical classroom setting. In a typical and functioning microteaching setting there should be a video tape for recording so that a learner can watch their mistakes when they get off the podium. In our microteaching laboratory at NUL we do not have this facility. The use of a videotape in microteaching is seen by many researchers as essential. It has benefits in teaching as it alerts everyone in the group to behaviour and events that they may have failed to notice at the time of the recording (Jacques, 2000).

The video tape recorder is a key equipment in microteaching which is meant to assist student teachers to look at how they conduct themselves in front of the class so that they can rectify mistakes committed while teaching. Quinn (2000) highlights that the person is then allowed to repeat the performance during which the changes suggested during the evaluation are incorporated into a new performance. On the other hand, there are authors like Minardi (1999) who argue that the use of video-taping and microteaching could also not be a good tool for learning as it cannot be effective. He offers a cautionary advice about microteaching and video recording by indicating that microteaching, although potentially valuable as an educational tool must be handled sensitively and requires further research to evaluate its effectiveness. The existing situation at the NUL is that when student teachers come into the microteaching laboratory, they come in batches of 10 . The nominated student teacher for the lesson proceeds with the pilot teaching and the supervisor then verbally gives out comments in the presence of others so that the next student teacher who will go to the podium will not commit the same mistakes. This has been found to be helpful as the students also learn from other students and reflect on the errors observed. Race (2001) asserted that setting up the environment for peers to observe each other provides a myriad of opportunities for the learner to learn about oneself and others, to build confidence, to practice how to give and receive positive and negative feedback.

\section{Research Problem}

This study was undertaken at the National University of Lesotho among the student teachers in the Faculty of Education. The study was to investigate the challenges student teachers experience when preparing and implementing micro teaching lessons. The issues that this study investigated were;

- The interpretation of curriculum document and syllabus

- The planning and implementation of lessons

- The relevance of teaching materials as well as applicability

\section{Methodology}

The study was conducted at the National University of Lesotho among the student teachers in the faculty of Education. This was where student teachers used microteaching laboratory. A 
qualitative approach was used in the design and selection of the methods that were used to collect data. The sample of this study consisted of 17 students who were involved in the programme from 17 student teachers for the academic year 2018/2019. van Zyl (2014) and; Creswell (2017) hold that qualitative research involves studying things in their natural settings, attempting to make sense of, or interpret, phenomena in terms of the meaning people bring to them. The data were collected through the observations of and semi-structured interviews with these student teachers during planning and implementation of microteaching lessons. Leedy and Ormrod (2015) outlined that qualitative researchers rarely try to simplify what they observe, instead they recognize that the issue that they are studying has many dimensions and layers, and so they try to portray the issue in its multifaceted form.

\section{Population and Sampling}

The population was made up of 386 were involved in the programme the National University of Lesotho, in the Faculty of Education and who were in the second year of their study while the sample consisted of 17 students from the population. The data was drawn during the preparation and implementation of their microteaching processes. A convenience sampling was used because student's teachers were readily available and accessible at all the time (Leedy \& Ormrod (2015); Maree (2019).

\section{Results}

\section{Demographic characteristics of the respondents}

Seventeen respondents were interviewed and observed while they were preparing and implementing microteaching. The respondents were made up of males and females; they were studying for bachelor degree in Education, Bachelor of Science in Education and Diploma in Agriculture Education. Among respondents, there were direct entry students from high schools. There were also those who attained Diploma in Education from Lesotho College of Education (LCE) and there were those who obtained Diploma in Agriculture from Lesotho Agricultural College (LAC). The respondents' ages ranged from 19 years to 45 years of age. The table below presents the demographic characteristics of the respondents.

Table 1: Frequency distribution of respondents by age

\begin{tabular}{|l|l|l|}
\hline Age Categories & Frequency & Percentage \\
\hline Younger than 20 Years & 7 & $41.17 \%$ \\
\hline 20- 25 Years & 4 & $23.52 \%$ \\
\hline 26- 30 Years & 3 & $17.64 \%$ \\
\hline 31- 35 Years & 2 & $11.76 \%$ \\
\hline Older than 35 Years & 1 & $5.88 \%$ \\
\hline Total & 17 & $100 \%$ \\
\hline
\end{tabular}

Source: Field Data 2019 
INTERNATIONAL JOURNAL OF ACADEMIC RESEARCH IN PROGRESSIVE EDUCATION AND

DEVELOPMENT

Vol. 9, No. 2, 2020, E-ISSN: 2226-6348 @ 2020 HRMARS

Table 2: Frequency distribution of respondents by sex

\begin{tabular}{|l|l|l|}
\hline Sex Categories & Frequency & Percentage \\
\hline Male & 6 & $35.29 \%$ \\
\hline Female & 11 & $64.70 \%$ \\
\hline Total & 17 & $100 \%$ \\
\hline
\end{tabular}

Source: Field Data 2019

Table 3: Frequency distribution of respondents by previous qualifications

\begin{tabular}{|l|l|l|}
\hline Qualification & Frequency & Percentage \\
\hline High School & 10 & $58.82 \%$ \\
\hline LAC Diploma & 2 & $11.76 \%$ \\
\hline LCE Diploma & 5 & $29.41 \%$ \\
\hline Total & 17 & $100 \%$ \\
\hline
\end{tabular}

Source: Field Data 2019

\section{Discussion of results}

The researcher came up with themes and sub-themes for the analysis of this this study. The identified themes are as language, Stage Fright, Interpretation of Syllabus, Over planning and under planning, teaching methods

\section{Language}

The study revealed that language is a problem for student teachers at the National University of Lesotho. Under language, the study was analyzed under three subheads three sub-themes: written English language, Spoken English Language and Non-conventional English Language.

\section{Written Language}

The study found that student teachers struggled with correct spelling of the English words used in their portfolio documents which included lesson plans. One respondent wrote:

At the end of that lesson students should be able to drawing plant cell. S.1

The above lesson objective showed two grammatical errors where student referred to the end of lesson as 'that' instead of 'the'. The other on is the tense mistake where the student used 'drawing' instead of 'draw'. These kinds of grammatical errors which included improper use of the tense were predominantly seen from most respondents. There were also some respondents who omitted some words while filling up lesson template. One respondent could not correctly copy down the end of level objective from the syllabus. The objective read:

At the end of Form A learners should able to participate on demographic processes. S.2

This level objective was written wrongly in two ways, firstly the respondent left out 'be' after should. The other shortcoming was found to be misapplication of English words so that instead of the word demographic referring to the structure of the population being sampled, the student uses the word "democratic". Therefore, the context and meaning of the whole lesson's objectives ended up confusing. The issues of spelling and grammatical errors continued to surface more during the presentation of some student teachers on the blackboards. It also became 
apparent that most student teachers did not adequately research their prescribed assignments prior to presentations.

\section{Spoken English Language}

The overall assessment of the student teachers elicited a serious problem in their spoken and written English during presentation of their lessons. The researcher witnessed one group of respondents arguing over the pronunciation of the word 'determine'. It took them some time arguing over the right pronunciation of the word. The findings further revealed that student teachers were not quite articulate in their use of the English Language to an extent that they kept on making long pauses during presentations as a way of trying to re-organise their sentence structure. One respondent uttered these words while declaring his public record. 'You should being able to explain on what hunting as an economic life of the Khoisan'. The student teacher meant to say 'At the end of this lesson you should be able to explain how hunting was used as an economic life of the Khoisan'.

\section{Non-Conventional Language}

The findings also revealed that most student teachers used non-conventional language or what is commonly known as "slang language" while administering their microteaching lessons. This practice was common and the researcher believes that it to be due to the reason that they are used to communicating among themselves with this un-conventional language. They tended to forget that microteaching is a formal and an academic exercise. One respondent said this verbatim 'I am gonna ask you to repeat after me the list of verbs so that you can remember them if you wanna use them'. This is regarded as one of the biggest challenges to the future of the national curriculum because it shows that student teachers are more likely to use nonconventional/slang language in the classrooms resulting in a negative perception to learners that this is an appropriate language use across the academic world. Gonzalez, Gonzalez, Martin, Martinez, Vegas, Herquedas and Hernandez (2015) concurred that the use of cell phones has led to language cut where people do not type the word in full while messaging.

\section{Stage Fright}

Student teachers exhibited a great difficulty standing in front of the audience as almost all of them were subjected to this situation for the first time. Symptoms of panicking, characterised by uncontrollable shivering, instability and lack of focus showed that student teachers developed stage fright. One respondent interrupted her presentation and excused herself by requesting the Clinical Supervisor for use of toilet facilities. The following day, this particular participant came to the office of the Clinical Supervisor and openly stated this 'Sir I am sorry that I had to leave the stage yesterday because I was too scared. As a result, I developed menstrual periods'. It was not uncommon to have student teachers literally cry while they stood in front of others to deliver their lessons.

\section{Interpretation of Syllabus}

The study also found that student teachers experienced the biggest problem on the interpretation of the Lesotho syllabus. The Lesotho syllabus is formatted in such a way that it 
should be easily interpreted and understood by the teacher who would administer it. Firstly, when the student teacher plans for the lesson they are required to develop indicators so that they are able to come up with end of lesson objectives from one end of level objectives. One of the challenges found was that some student teachers wanted to teach end of level objectives within the first ten minutes without breaking it down into lesson objectives first.

The findings also revealed that respondents also put more emphasis on the topics. They worked on topics as a lesson objective without looking at the end of level objective. Most of the student teachers had a misconception that they could conclusively teach a particular topic within the stipulated short period of time. One respondent argued that she could teach 'weathering' within ten minutes. When interpreting syllabus, one has to take into consideration that there are many end of lesson objectives under weathering which include definition, types, causes etc.

\section{Over Planning and Under Planning}

The study found that over planning and under planning is common among student teachers. As mentioned the lesson plans are screened by the supervisor before students teachers can go into the microteaching laboratory. The process of screening each student's planning involves all aspects of the lesson plan template from allocation of time to lesson evaluation. The researcher observed that some students over plan either by designing too many lesson objectives or by designing one ambiguous lesson objective. The researcher has provided the following lesson objective which were formulated by the student teachers while preparing their lesson.

\section{History}

At the end of the lesson, students should be able to:

1. Explain marriage as a social life of the Khoisan

2. Explain religion as a social life of the Khoisan

3. Explain hunting as part of an economic life of the Khoisan

4. Explain gathering as part of an economic life of the Khoisan

5. Explain chieftaincy as part of a social life of the Khoisan

From the listed lesson objectives above, it is clear that there is no student teacher who can teach these objectives within a space of 10 minutes. These objectives are well designed but they cannot be taught in one day, as they are many sub items with lots of contents that needs to be explored and explained.

\section{Sesotho (Local Language)}

Qetellong ea seruoatoa, ban aba be baka hlalosa ka bophara moetlo oa lenyalo la Sesotho ka methati e lokelang ho lateloa

This objective translates to 'At the end of the lesson, students should be able to describe chronologically in details Sesotho traditional marriage'. It is one objective but it is quite impossible for a student to teach this within 10 minutes, as there are different phases that have to be executed in the process of establishing a Sesotho marriage and its explanation is a daunting task. For an example; Ho raha moritsoana, ho kopa mohope oa metsi, peheletso/tebeletso, selelekela etc. This is over planning because this involves lots of content which can be taught for days. It reflects over planning in the sense that it is exactly same with the end of level object that 
is meant to be annual content to be covered. This was observed by the researcher as lesson over planning which, was done by many students teachers across all disciplines.

This study also revealed that some student teachers under planned while they were designing their lesson plans. They are some who used multiple lesson objectives with the misconception that if they were many they would be appropriate for the lesson while others thought that one lesson could appropriately be dispensed off in 10 minutes. The following lesson objectives are typical examples on two subjects: Geography and Biology.

\section{Geography}

At the end of the lesson, students should be able to:

1. List types of soil erosion

2. List causes of soil erosion

3. List conservation methods

4. List problems caused by erosion

Teaching the above objectives would require a teacher less time as topics covered are all about listing components without going deeper with their explanations or descriptions.

\section{Geography}

At the end of the lesson, students should be able to list parts of the root hair cell.

This lesson objective also sets out as an example of a single under planned lesson objective which could also be taught within limited time by the student teacher.

\section{Teaching Methods}

The study found that students do not have a clear understanding of the teaching methods, student teachers wrote on the lesson plan that they would use particular teaching method and when they conducted their lesson, they used different teaching methods from the one they proposed to use. There are respondents who suggested the use of a particular teaching method say 'discussion', but later changed to a different method say 'discovery or question and answer' during their lesson presentation. There were those who would propose on the lesson plan simultaneous use of three teaching methods on one lesson objective. This demonstrated a lack of understanding of how teaching methods should be used. Below is a common example of how most respondents used the teaching methods.

\begin{tabular}{|l|l|l|l|l|l|l|l|}
\hline $\begin{array}{l}\text { Stages } \\
\text { of } \\
\text { Lesson }\end{array}$ & $\begin{array}{l}\text { Specific } \\
\text { Objectives }\end{array}$ & Duration & Content & $\begin{array}{l}\text { Teaching } \\
\text { Method }\end{array}$ & Media & $\begin{array}{l}\text { Teacher } \\
\text { Activity }\end{array}$ & $\begin{array}{l}\text { Learner } \\
\text { Activity }\end{array}$ \\
\hline Body & $\begin{array}{l}\text { Objective } \\
1\end{array}$ & $\begin{array}{l}10 \\
\text { minutes }\end{array}$ & Verb & $\begin{array}{l}\text { Discussion } \\
\text { Demonstration } \\
\text { Discovery }\end{array}$ & & $\begin{array}{l}\text {-Defines } \\
\text { a verb }\end{array}$ & $\begin{array}{l}\text {-Defines } \\
\text { a verb }\end{array}$ \\
\hline
\end{tabular}

\section{Organisational Strategies}

The study found out that student teachers had a host of problems when it comes to organisational strategies. Most student teacher groupings experienced internal conflicts of interest. If for example one section of the group may want to schedule a microteaching lesson, 
say, for two hours' duration, there would be members of this grouping who would not show up thus causing havoc for others. This section of the grouping would always cite flimsy reasons as to why they abstained. One of the most common reason was found to be the fact that during the formation of the grouping, some members neglected to properly check their school timetables in order to agree on a time slot for the microteaching lesson that would be suitable for all members. The multiple and varied course of studies pursued by individual members commonly pursuing the microteaching was another challenge to be reckoned with. . For example, the researcher found out that in one grouping which was made up of ten members, there were two students who were majoring in science subjects and other varying courses as History, Development studies, Sesotho, English Language and Business Education.

The study further revealed that, there was a challenge also on the organisational strategies of student teachers on the compilation of a portfolio. It was common to find that other student teachers, either due to laziness or lack of self-confidence, would copy the compiled work portfolio of other student teachers. The researcher found out that a student teacher would write Development Studies as a subject to be taught in the microteaching only to realize that the student teacher planned the contents for a History lesson, whereas the prepared work was for Development Studies.

\section{Conclusion}

Based on the findings gathered, the following conclusion can be drawn from this present study:

$>\quad$ The use of spoken and written English prescribed as a medium of study and the adoption of non-conventional language or slang appears to be the obstacle for student teachers at the National University of Lesotho. This study leads to a conclusion that lack of mastery of the English Language for the learners at the National University of Lesotho in the faculty of Education is a very serious national problem.

$>\quad$ Stage fright was found to be one of the challenges that student teachers encountered as noticeable signs of panicking, uncontrollable shivering, instability and lack of focus were detected.

$>\quad$ Correct interpretation of subject syllabi is the other challenge that was observed as student teachers struggled to come up with indicators to break up end-of-level objective into manageable lesson objectives.

$>\quad$ The study also revealed that students could not prepare appropriate lessons with appropriate timings. There were some who over planned while there were others who under planed their lessons duration for the estimated 10 minutes' practice.

$>\quad$ Lastly, the study concluded that student teachers could not differentiate between teaching methods; they do not understand teaching methods. Most of them used different teaching methods from the one they have written on the lesson plan template.

$>\quad$ Lastly, the organisational strategy, teamwork, collaboration and cooperation were also observed to pose challenges to the student teachers as they kept on reporting to the course instructor about their differences and group conflicts.

\section{Recommendations}

Based on these findings, the study recommends that: 
Vol. 9, No. 2, 2020, E-ISSN: 2226-6348 C 2020 HRMARS

$>\quad$ The student teachers should proofread to avoid grammatical errors before submitting their work for clinical supervision.

The use of non-conventional language commonly known as slang language should be eliminated during lesson planning and presentation.

This study recommends that student teachers should align their lessons planning, based on the subject syllabus, with the National Curriculum and Assessment Policy of Lesotho. The interpretation of the syllabus where student teachers will interpret syllabus using indicator will illuminate challenges like over planning and under planning.

$>\quad$ This study further recommends that student teachers should familiarise themselves with different teaching methods so that they can select the appropriate ones for different context.

$>\quad$ Lastly, it is recommended that student teachers prepare their portfolio, which includes lesson planning way ahead so that they can have ample time to reflect on their work and to avoid any associated challenge.

\section{References}

Bagatur, T. (2015). The perceptions of EFL prep school students on their listening skills: A Qualitative study. Social and behavioural Sciences. 2 (32), 806-812.

Bell, N. D. (2007). Microteaching: What is going on here? Linguistic and education. $18,2440$.

Biggam, J. (2008). Succeeding with your Master's Dissertation: A step-by-step handbook. McGraw-Hill: Open University Press.

Bryman, A. (2014). Social Research Methods. (4 ${ }^{\text {th }}$ ed.). New York: Oxford University Press.

Cheptyator-Thomson, R., and Hsu, S. (2007). Student Teaching: Preservice Teachers Perspectives and Experiences. Educational Research Journal. 1 (22), 23-48.

Cohen, L., Manion, L., \& Morrison, K. (2007). Research methods in education. ( $7^{\text {th }}$ ed.) London: Routledge.

Creswell, J. W. (2017). Educational Research. (6 th $^{\text {ed. }}$.). Boston: Pearson.

Council on Higher Education. (2010). CHE report on the national review of academic and professional programme in education. CHE Monitor No 1, August 2010. CHE, Maseru, Lesotho

Darling-Hammond, L. (2006). Powerful Teacher Education: Lessons from exemplary Programs. San Francisco: Jossey-Bass.

Gonzalez, M. A., Gonzalez, M. A., Martin, E., Martinez, O., Vegas, J., Herquedas, M., and Hernandez, C. (2015). Teaching and Learning Physics with Smartphones. Journal of cases on Information Technology. 17 (1), 252-270.

Higgins, A., \& Nicholl, H. (2003). The experiences of Lectures and students in the use of Microteaching as a strategy. Nurse Education in Practice. 3, 220-227.

Jacques, D. (2000). Learning in groups. ( $3^{\text {rd }}$ ed.). London: Kogan Page.

Leedy, D., and Ormrod, T. E. (2015). Practical Research Planning and Design. Cape Town: Pearson Education International.

Lewin, F. (2004). Rethinking teaching teacher education and development - Can other models 
Provide a solution for improving teacher training programmes? South Africa. Western Cape Education Department.

Maree, K. (2019). First steps in research. Pretoria: Van Schaik.

National University of Lesotho. (2019). NUL Prospectus for 2019/2020. Roma: National University of Lesotho.

Okeke, C., Abongdia, J., Adu, E. O., and Wolhuter, C. (2019). Learn to Teach: A Handbook For Teaching Practice. South Africa: Oxford University Press.

Remesh, A. (2013). Microteaching, an effective technique for learning effective teaching. Journal of Research in Medical Sciences. 18 (2), 158-163.

Rice, R. (2004). The student teacher's perspectives on challenge within teaching practice. Paper presented at the British Educational Research Association Annual Conference, 1618 September. Manchester: University of Manchester.

Thanh, N. C., and Thanh, T. T. (2015).The interconnections between interpretive paradigm and qualitative methods in education. Vietnam: American Institute of Science.

Quin, F. M. (2000). Principles and Practice of Nurse education. ( $4^{\text {th }}$ ed.). Cheltenham: Stanley Thrones Publishers.

United States Agency foe International Development. (2015). Designing Effective Pre-service teacher Education Programs. Compendium: USAID.

Van Zyl, L. E. (2014). Research Methodology for the Economic and Management Sciences. Cape Town: Pearson.

Wagennar, R., and Gonzalez, J. (2005). Turning Educational structures in Europe II. Universities Contribution to the Bologna Process. Education and Culture. Socrates: de la Universidad de Deusto. 